\title{
IMPLEMENTASI IOT (INTERNET OF THINGS) PADA RUMAH BUDIDAYA JAMUR TIRAM PUTIH
}

\author{
Tareh Rozzaq Adzdziqri, Yosep Agus Pranoto, Deddy Rudhistiar \\ Program Studi Teknik Informatika S1, Fakultas Teknologi Industri \\ Institut Teknologi Nasional Malang, Jalan Raya Karanglo km 2 Malang, Indonesia \\ 1718033@scholar.itn.ac.id
}

\begin{abstract}
ABSTRAK
Indonesia merupakan salah satu negara berkembang yang sumber pencaharian utamanya berada pada sektor pertanian, yakni salah satunya adalah pertanian jamur tiram putih. Dalam pembudidayaan jamur tiram putih tersebut, ternyata masih terdapat beberapa permasalahan. Karena, sampai saat ini sistem budidaya jamur tiram putih masih dilakukan secara manual. Seperti misalnya untuk memantau keadaan suhu, kelembapan, kadar $\mathrm{pH}$, dan kapasitas air pada wadah asam dan basa yang tentu saja manajemen waktunya belum dianggap efektif. Untuk membantu permasalahan tersebut, dikembangkanlah sistem monitoring pembudidayaan jamur tiram putih berbasis IoT (Internet Of Things). Dengan sistem ini dapat dilakukan monitoring jarak jauh pada sistem atau alat dengan menggunakan media website. Disamping itu, ditambahkan pula tindakan antisipasi berupa fan dc sebagai aktuator untuk menurunkan suhu, heather sebagai aktuator untuk menaikan suhu, lalu humidifier untuk meningkatkan kelembapan udara, 2 pompa air yang berisikan kapur dan cuka untuk mengatur kadar $\mathrm{pH}$, dan 2 pompa air lagi untuk mengisi kembali air kapur dan cuka jika pada wadah sebelumnnya sudah habis. Hasil pengujian menunjukkan bahwa sensor diketahui memiliki rata - rata presentase error pada sensor DHT22 untuk suhu memiliki presentase error 1,28\% dan untuk kelembapan udara memiliki presentase error 2,93\%., sensor kadar $\mathrm{pH}$ tanah memiliki presentase error 3,46\%, dan sensor ultrasonic memiliki presentase error 1,59\%. Dalam pengujian komunikasi dan pengiriman data menggunakan modul ESP8266 (NodeMcu) berhasil terhubung dan mengirimkan data ke database lalu tampil dengan baik pada website dan delay waktu pengiriman data sebesar 10 detik. Website berjalan dengan baik pada beberapa web browser yang ujikan yaitu Google Chrome (87.0.42), Microsoft Edge (86.0.2), Mozilla Firefox (83.0) karena aplikasi merupakan website reponsif yang dibuat menggunakan program PHP.
\end{abstract}

Kata kunci : Internet of Things, Monitoring ,Budidaya, Jamur Tiram Putih

\section{PENDAHULUAN}

Jamur tiram putih merupakan salah satu jamur yang dibanyak dibudidayakan oleh petani di Indonesia yang memang mata pencahariannya bersumber dari sektor pertanian. Jamur tiram putih (Pleurotus ostreatus) digolongkan ke dalam organisme yang berspora, memiliki inti plasma, tetapi tidak berklorofil [1]. Lalu kandungan nutrisi pada jamur tiram putih ini lebih baik dibandingan dengan jenis jamur lainnya. Jamur tiram mempunyai kandungan nilai gizi yang baik. Serta, memiliki manfaat pada kesehatan yaitu sebagai protein nabati yang tidak mengandung kolesterol sehingga dapat mencengah timbulnya penyakit darah tinggi dan jantung [2]. Jamur tiram putih ini dapat tumbuh dengan baik dan berkualitas apabila suhu dan kelembaban sesuai dengan suhu yang dibutuhkan oleh jamur. Agar jamur tiram putih tumbuh optimal dibutuhkan kriteria ideal yaitu berada di kisaran $26-28^{\circ} \mathrm{C}$ dan kadar $\mathrm{pH}$ optimum pada media tanam jamur tiram putih berkisar 6 - 7 dengan kelembapan udara $80 \%$ - 90\%. [3]

Namun, pada kenyataannya, masih banyak pembudidaya jamur yang mengalami kendala pada proses budidaya jamur tiram putih. Hal ini disebabkan oleh, sistem budidaya jamur tiram putih masih dilakukan secara manual. Seperti misalnya untuk memantau keadaan suhu, kelembapan, dan kadar $\mathrm{pH}$, yang tentu saja manajemen waktunya belum dianggap efektif.

Untuk membantu permasalahan tersebut, dibutuhkan suatu sistem baru yang lebih efektif. Oleh karena itu, dikembangkanlah sistem monitoring pembudidayaan jamur tiram putih berbasis IoT (Internet of Things). Dengan sistem ini dapat dilakukan monitoring jarak jauh pada sistem atau alat dengan menggunakan media website. Disamping itu, ditambahkan pula tindakan antisipasi berupa fan dc sebagai aktuator untuk menurunkan suhu, heather sebagai aktuator untuk menaikan suhu, lalu humidifier untuk meningkakan kelembapan udara, dan adanya 2 pompa air yang berisikan kapur dan cuka untuk mengatur kadar $\mathrm{pH}$ dan 2 pompa air lagi untuk mengisi kembali air kapur dan cuka jika pada wadah sebelumnya sudah habis.

\section{TINJAUAN PUSTAKA}

\subsection{Penelitian terdahulu}

Pada 2018 lalu, terdapat penelitian berjudul "Implementasi Sistem Monitoring Pada Rumah Jamur Menggunakan Jaringan Nirkabel Berbasis Protokol Komunikasi Message Queuing Telemetry Transport (MQTT)" yang ditulis oleh Nugraha Pangestu, Rizal Maulana, dan Rakhmadhany Primananda yang bertujuan untuk memudahkan petani dalam melakukan 
budidaya jamur dan dibutuhkan sistem monitoring untuk memantau suhu dan kelembapan pada rumah jamur menggunakan protocol MQTT. Dalam penelitian ini, digunakan sensor DHT22 untuk mendeteksi suhu dan kelembapan pada rumah jamur lalu, data dari sensor akan diproses oleh mikrokontroller Arduino dan dikirimkan menggunakan protocol MQTT dan data akan ditampilkan dalam bentuk chart dan grafik. [4]

Ditahun yang sama, pada 2018, terdapat pula penelitian serupa yang berjudul "Sistem Monitoring Dan Kontrol Suhu Serta Kelembaban Budidaya Jamur Tiram Berbasis Wireless Sensor Network" yang ditulis oleh Dewi, Kartika, dan Hafsah Nirwana. Sistem ini menerapkan pembudidayaan jamur tiram melalui koneksi internet dari perangkat Raspberry Pi dengan mengirim data monitoring dan status pengontrolan berdasarkan kondisi lingkungan. Hasil data yang diolah Raspberry Pi tersebut selanjutnya akan dikirm ke server untuk di simpan datanya dan tampilkan menjadi sistem informasi monitoring berupa web server. [5]

Masih ditahun yang sama yakni pada 2018, terdapat penelitian serupa yang berjudul "Perancangan Smart Monitoring System Pada Pembudidayaan Jamur Tiram Berbasis Pemrograman Arduino Dan Labview" yang ditulis oleh Soulthan, Deza Rijabi, dan Dwi Ana Ratna Wati. Penelitian ini bertujuan untuk pengadaan sistem monitoring cerdas untuk suhu dan kelembapan pada pembudidayaan jamur tiram akan berbasis pada pemograman Arduino dan LabView serta hasil monitoring akan di logging pada excel untuk bisa dievaluasi oleh petani jamur. [6]

Pada 2019 lalu, terdapat penelitian berjudul "Prototipe Sistem Monitoring Serta Kendali Suhu dan Kelembapan Ruangan Budidaya Jamur Tiram Putih Menggunakan Sensor DHT22 dan Mikrokontroller NodeMcu" yang ditulis oleh Isnan Yusrian Syas, Frida Agung Rakhmadi. Tujuan dari penelitian ini adalah membuat prototype sistem monitoring dan kendali suhu serta kelembapan ruangan budidaya jamur tiram putih menggunakan sensor DHT22, Kipas, mist taker, NodeMcu dan aplikasi Blynk. Dimana penelitian ini mendapatkan pengujian sistem kendali memperoleh tingkat keberhasilan 100\%, karena kipas dan mist taker bekerja sesuai perintah yang diberikan. Hasil dari penerapan sistem menunjukan bahwa pertumbuhan jamur tiram putih yang terkontrol menjadi lebih baik dibandingkan jamur tiram putih yang tanpa kontrol. [7]

Selanjutnya ditahun 2020, terdapat penelitian berjudul "Penerapan Iot (Internet Of Thing) Terhadap Sistem Pendeteksi Kesuburan Tanah Pada Lahan Perkebunan" yang ditulis oleh Sinambela, Lazro Eko Putra Daniel. Penelitian ini bertujuan untuk menciptakan sistem monitoring pendeteksi kesubururan tanah yang berfungsi untuk mengetahui kelayakan suatu daerah pertanian atau penilaian kelayakan jenis tanaman yang cocok ditanam dilahan tersebut. Dengan adanya perangkat atau sistem ini akan lebih mempermudah pengguna dalam memantau maupun mendapatkan informasi tentang pertanian baik daerah maupun jenis tanaman pertanian. [8]

Berdasarkan penelitian - penelitian terdahulu dengan mengimplementasikan IoT (Internet Of Things ) pada rumah budidaya jamur tiram putih mampu memudahkan user (petani) dalam hal melakukan monitoring rumah budidaya jamur tiram putih dikarenakan dalam IoT (Internet Of Things) memungkin sensor dan aktuator berkolaborasi lalu melakukan tindakan berdasarkan informasi yang didapat secara independen.

\subsection{IoT (Internet Of Things)}

IoT yang merupakan singkatan dari Internet of Things adalah suatu konsep yang mampu memperluas manfaat dari konektivitas internet, yang memungkinkan kita untuk dapat menghubungkan mesin, peralatan, dan benda fisik lainnya dengan suatu sensor jaringan dan aktuator untuk memperoleh data dan mengelola kinerjanya sendiri. Sehingga memungkinkan mesin untuk berkolaborasi dan bahkan dapat bertindak berdasarkan informasi baru yang diperoleh secara independen. [9]

\subsection{NodeMcu}

NodeMCU pada dasarnya adalah pengembangan dari ESP 8266 dengan firmware berbasis e-Lua. NodeMcu dilengkapi dengan micro $u s b$ port yang berfungsi untuk pemograman maupun power supply. [10]

\subsection{Arduino Uno R3}

Arduino Uno R3 adalah papan pengembangan mikrokontroler yang berbasis chip ATmega328P. Arduino Uno memiliki 14 digital pin input / output (atau biasa ditulis I/O, dimana 14 pin diantaranya dapat digunakan sebagai output PWM antara lain pin 0 sampai 13), 6 pin input analog, menggunakan crystal $16 \mathrm{MHz}$ antara lain pin A0 sampai A5, koneksi USB, jack listrik, header ICSP dan tombol reset. .[11]

\subsection{Sensor Ultrasonik}

Sensor ultrasonik HC-SR04 adalah seri dari sensor jarak dengan gelombang ultrasonik, dimana didalam sensor terdapat dua bagian yaitu transmitter yang berfungsi sebagai pemancar gelombang dan receiver yang berfungsi sebagai penerima gelombang. Sensor ultrasonik HC-SR04 ini bisa digunakan untuk mengukur jarak benda dari $2 \mathrm{~cm}-400 \mathrm{~cm}$ dengan akurasi $3 \mathrm{~mm}$. [12]

\subsection{Sensor DHT22}

Sensor DHT22 adalah adalah sensor suhu dan kelembaban, sensor ini memiliki keluaran berupa sinyal digital dengan konversi dan perhitungan dilakukan oleh MCU 8-bit terpadu. Sensor ini memiliki kalibrasi akurat dengan kompensasi suhu ruang penyesuaian dengan nilai koefisien tersimpan dalam memori OTP terpadu. .[13] 


\subsection{Sensor Kadar pH Tanah}

Sensor $\mathrm{pH}$ tanah merupakan sensor pendeteksi tingkat keasaman (acid) atau kebasaan (alkali) pada tanah. Sensor ini dapat langsung disambungkan dengan pin analog Arduino maupun pin analog mikrokontroller lainnya. [14]

\subsection{Humidifier}

Humidifier adalah suatu alat yang berfungsi untuk melembapkan udara yang bekerja dengan cara menyemprotkan uap air ke udara. Uap air daru alat inilah yang akan meningkatkan kelembapan udara sehingga berada dalam kisaran yang ditentukan atau ideal. [15]

\subsection{Pompa Air}

Pompa air ini termasuk dalam kategori pompa air yang fleksibel. Karena memiliki desain yang ringkas yakni, berukuran $56 \mathrm{~mm} \times 52 \mathrm{~mm} \times 47 \mathrm{~mm}$. Proses pemasangan pompa ini juga cukup mudah dan praktis. Pompa air ini dapat dicelupkan ke dalam air karena bersifat sumersible [16]

\subsection{Buzzer}

Buzzer adalah suatu komponen elektronik yang memiliki fungsi untuk mengubah suatu getaran listrik menjadi suatu getaran suara. Buzzer biasanya digunakan sebagai sebuah tanda atau indikator bahwa proses yang terjadi telah selesai atau proses tersebut menimbulkan suatu kesalahan dalam sebuah alat.[17]

\subsection{Fan DC}

Fan DC adalah suatu alat yang memiliki fungsi untuk menjaga suhu udara agar tetap stabil dan tidak melewati batas suhu yang di tentukan. Kipas angin banyak digunakan sebagai pembuang panas (exhaust fan) atau penurun suhu pada suatu perangkat elektronik maaupun pada perangkat komputer dengan menggunakan arus DC berkekuatan 12 Volt. [18]

\subsection{Relay}

Relay adalah suatu peranti atau saklar elektronis yang bekerja berdasarkan elektromagnetik untuk menggerakan sejumlah kontaktor yang tersusun atau dapat dikendalikan dengan rangkaian elektronik lainnya dengan memanfaatkan tenaga listrik sebagai sumber energinya. [19]

\section{METODE PENELITIAN}

\subsection{Analisa Kebutuhan Fungsional}

Adapun beberapa kebutuhan fungsional dalam rancang bangun sistem Implementasi IoT (Internet Of Things) Pada Rumah Budidaya Jamur Tiram Putih antara lain :
Tabel 1. Kebutuhan Fungsional

\begin{tabular}{|c|l|l|}
\hline No. & \multicolumn{1}{|c|}{ Hardware } & \multicolumn{1}{|c|}{ Software } \\
\hline 1 & NodeMcu & 1.8 .13 \\
\hline 2 & Arduino Uno & Sublime Text 3 \\
\hline 3 & Modul ESP8266 (NodeMcu) & XAMPP \\
\hline 4 & Sensor Ultrasonik HC-SR04 & Web browser \\
\hline 5 & $\begin{array}{l}\text { Sensor Suhu dan Kelembapan } \\
\text { Udara DHT22 }\end{array}$ & - \\
\hline 6 & Sensor Kadar pH Tanah & - \\
\hline 7 & Humidifier & - \\
\hline 8 & Pompa Air & - \\
\hline 9 & Buzzer & - \\
\hline 10 & Fan DC & - \\
\hline 11 & Relay & - \\
\hline
\end{tabular}

\subsection{Desain Rangkaian}

Perangkat yang digunakan dalam pembuatan sistem monitoring pada rumah budidaya jamur tiram putih terdiri dari : NodeMcu, Arduino Uno, Sensor Ultrasonik, Sensor DHT22, Sensor kadar pH tanah, 4 buah Pompa Air, Buzzer, Heather, humidifier dan Relay. Desain rangkaian ditunjukkan pada Gambar 1.

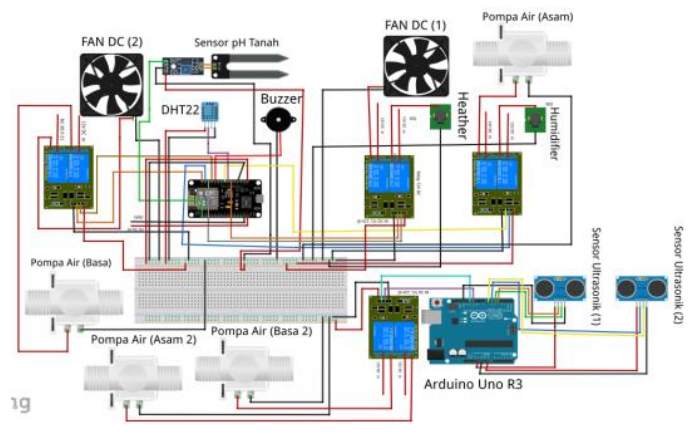

Gambar 1. Desain Rangkaian

\subsection{Diagram Blok Sistem Monitoring Pada Rumah Budidaya Jamur Tiram Putih}

Sistem monitoring pada rumah budidaya jamur tiram putih menggunakan Mikrokontroller NodeMcu dan Arduino Uno sebagai pusat pengelola data. Data suhu $\left({ }^{\circ} \mathrm{C}\right)$, kelembapan udara $(\%)$, dan kadar $\mathrm{pH}$ tanah dideteksi oleh 2 sensor yaitu sensor DHT22 dan sensor kadar $\mathrm{pH}$ tanah yang terhubung ke NodeMcu. Lalu data kapasitas air $(\mathrm{Cm})$ dideteksi oleh sensor ultrasonic yang terhubung ke Arduino. Selanjutnya Arduino mengirimkan data kapasitas air asam dan basa kepada NodeMcu, lalu diolah oleh NodeMcu dan diteruskan melalui modul ESP8266 disimpan ke dalam database. Kemudian data yang sudah terkirim dapat ditampilkan pada website sehingga dapat dilihat oleh user. Blok diagram sistem monitoring pada rumah budidaya jamur tiram putih dapat dilihat pada Gambar 2. 


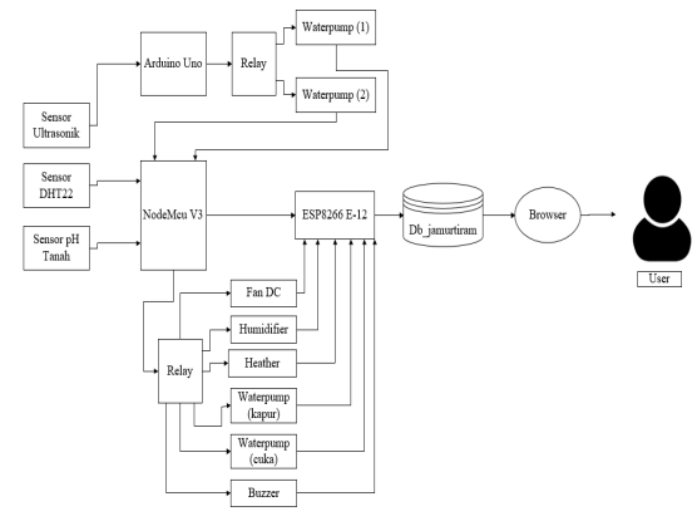

Gambar 2. Diagram blok sistem monitoring pada rumah budidaya jamur tiram putih

\subsection{Alokasi Pin}

Berikut adalah Alokasi pin untuk sistem monitoring sensor dan aktuator dapat dilihat pada Tabel 2.

Tabel 2. Alokasi pin sistem monitoring

\begin{tabular}{|c|c|c|c|}
\hline No & Alat & No Pin & Tegangan \\
\hline 1. & Sensor DHT22 & Gnd,Vcc, D6 & $3 \mathrm{v}$ \\
\hline 2. & Sensor $\mathrm{pH}$ Tanah & Gnd, Vcc, A0 & $3 \mathrm{v}$ \\
\hline 3 & Sensor Ultrasonik (1) & $\begin{array}{l}\text { Gnd, Vcc, D4, D5 } \\
\text { (Arduino) }\end{array}$ & $5 \mathrm{v}$ \\
\hline 4 & Sensor Ultrasonik (2) & $\begin{array}{c}\text { Gnd, Vcc, D6, D7 } \\
\text { (Arduino) }\end{array}$ & $5 \mathrm{v}$ \\
\hline 5 & Waterpump $12 \mathrm{~V}$ (asam) & Gnd, Vcc, Do & $12 \mathrm{v}$ \\
\hline 6 & Waterpump $12 \mathrm{~V}$ (basa) & Gnd, Vcc, D1 & $12 \mathrm{v}$ \\
\hline 7. & $\begin{array}{c}\text { Waterpump 12 V } \\
\text { (asam 2) }\end{array}$ & $\begin{array}{l}\text { Gnd, Vcc, D11 } \\
\text { (Arduino) }\end{array}$ & $12 \mathrm{v}$ \\
\hline 8 & $\begin{array}{l}\text { Waterpump 12V } \\
\text { (basa 2) }\end{array}$ & $\begin{array}{l}\text { Gnd, Vcc, D12 } \\
\text { (Arduino) }\end{array}$ & $12 \mathrm{v}$ \\
\hline 9. & Fan DC $12 \mathrm{~V}(1)$ & Gnd, Vcc, D5 & $12 \mathrm{v}$ \\
\hline 10. & Fan DC $12 \mathrm{~V}(2)$ & Gnd, Vcc, D7 & $12 \mathrm{v}$ \\
\hline 11. & Humidifier & Gnd, Vcc, D4 & $12 \mathrm{v}$ \\
\hline 12. & Heather & Gnd, Vcc, D3 & $12 \mathrm{v}$ \\
\hline 13. & Buzzer & Gnd, D2 & $5 \mathrm{v}$ \\
\hline
\end{tabular}

Pada tabel diatas sensor DHT22 dan Sensor kadar $\mathrm{pH}$ tanah terhubung dengan vcc dan gnd (ground) dari NodeMcu. Untuk sensor ultrasonic terhubung dengan vcc dan gnd dari Arduino Uno. sedangkan aktuator terhubung dengan vcc dan gnd dari relay. Sensor kadar $\mathrm{pH}$ tanah dihubungkan pada pin $\mathrm{A} 0$.

\subsection{Struktur Menu Website}

Website monitoring pada Sistem monitoring pada rumah budidaya jamur tiram putih terdiri dari tiga halaman utama yaitu halaman home, data grafik, dan data log. Berikut stuktur menu pada website dapat dilihat pada gambar 3 .

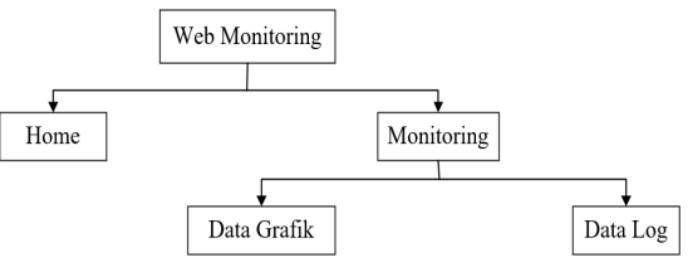

Gambar 3. Struktur menu website

Penjelasan masing - masing struktur menu pada website :
1. Home mempunyai fungsi untuk menampilkan informasi data secara real time dengan data terbaru dan adanya tampilan informasi kondisi dan aktuator

2. Data Grafik mempunyai fungsi untuk menampilkan grafik data suhu $\left({ }^{\circ} \mathrm{C}\right)$, kelembapan udara $(\%)$, kadar $\mathrm{pH}$ tanah, kapasitas air asam $(\mathrm{cm})$, dan kapasitas air basa $(\mathrm{cm})$.

3. Tampilan Halaman Data Log mempunyai fungsi untuk menampilkan riwayat data monitoring.

\subsection{Desain Arsitektur Sistem}

Desain arsitektur sistem menjelaskan alur dari berjalannya sistem monitoring dan antisipasi otomatis. Pada desain arsitektur terdapat 3 tahapan yaitu : input, proses, dan output. Desain Arsitektur sistem bisa dilihat pada gambar 4.

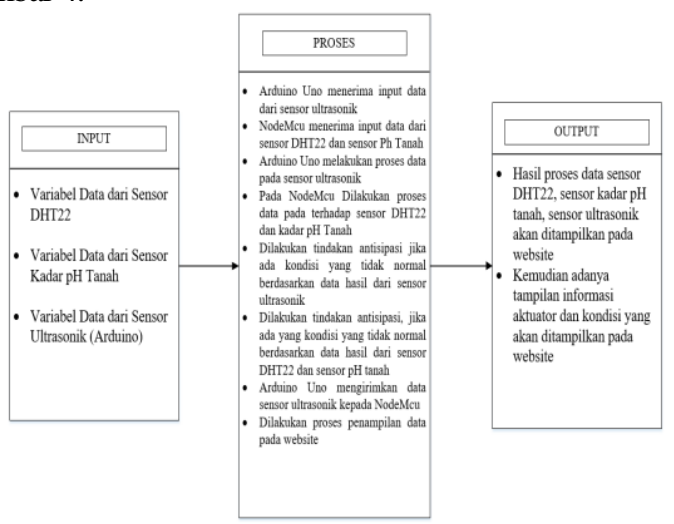

Gambar 4. Desain Arsistektur Sistem

Penjelasan masing - masing tahapan pada desain arsitektur sistem :

1. Tahap Input merupakan penjabaran tentang analisa input data pada sistem monitoring pada rumah budidaya jamur tiram putih dengan pengolahan input sumber data sensor DHT22, sensor kadar $\mathrm{pH}$ tanah, dan sensor ultrasonik.

2. Tahap proses merupakan hasil input data sudah dilakukan pada proses sebelumnya dikelola agar menjadi output yang diinginkan. Dalam tahap proses dilakukan pemrosesan data menjadi sebuah tindakan monitoring dan antisipasi.

3. Tahap output merupakan tampilan keluaran yang akan dihasilkan adalah berupa informasi data suhu, kelembapan udara, kadar $\mathrm{pH}$, kapasistas air asam dan basa, tampilan informasi kondisi dan aktuator yang akan ditampilkan pada website.

\subsection{Flowchart Sistem}

Flowchart sistem ini menjelaskan proses berjalanan sistem monitoring pada rumah budidaya jamur tiram putih seperti ditunjukan pada Gambar 5 dan gambar 6 . 


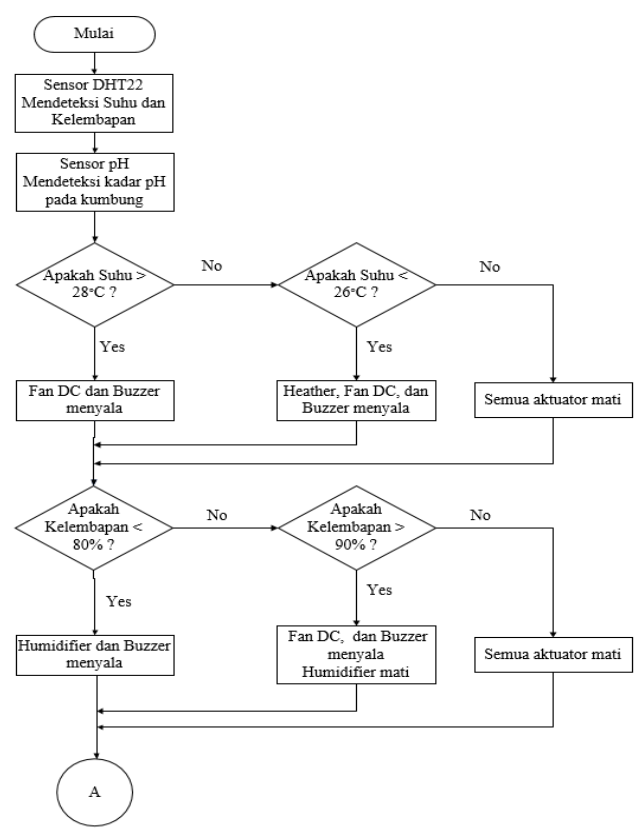

Gambar 5. Flowchart Sistem (1)

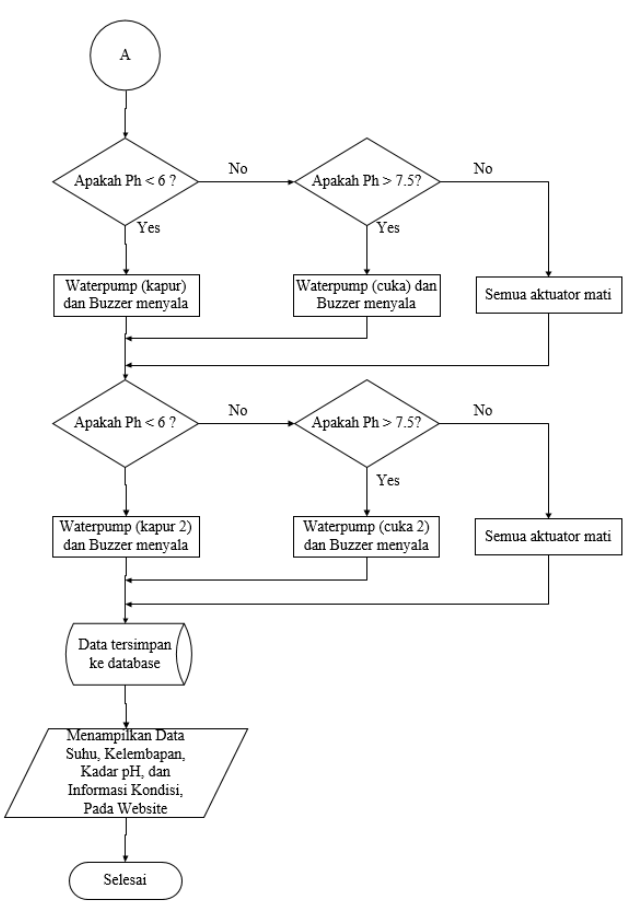

Gambar 6. Flowchart Sistem (2)

\section{HASIL DAN PEMBAHASAN}

\subsection{Pengujian Sensor DHT22}

Pengujian Sensor suhu dan kelembapan udara DHT22 dilakukan dengan cara membandingkan kadar suhu dan kelembapan udara yang dideteksi oleh sensor dengan kadar suhu dan kelembapan udara yang dideteksi oleh alat Hygrometer HTC-2.. Hasilnya bisa dilihat pada tabel 3 untuk suhu dan pada tabel 4 untuk kelembapan udara.
Tabel 3. Pengujian Sensor DHT22 (Suhu)

\begin{tabular}{|c|c|c|c|c|}
\hline \multirow[b]{2}{*}{ No } & \multicolumn{2}{|c|}{ Hasil baca Suhu } & \multirow[b]{2}{*}{ Selisih } & \multirow{2}{*}{$\begin{array}{c}\text { Kesalahan } \\
(\%)\end{array}$} \\
\hline & $\begin{array}{c}\text { Sensor } \\
\text { DHT22 }\end{array}$ & Hygrometer HTC-2 & & \\
\hline 1 & $25^{\circ} \mathrm{C}$ & $25,7^{\circ} \mathrm{C}$ & 0,7 & $2.72 \%$ \\
\hline 2 & $26^{\circ} \mathrm{C}$ & $26,2^{\circ} \mathrm{C}$ & 0,2 & $0,76 \%$ \\
\hline 3 & $27^{\circ} \mathrm{C}$ & $27,5^{\circ} \mathrm{C}$ & 0,5 & $1,8 \%$ \\
\hline 4 & $26^{\circ} \mathrm{C}$ & $26^{\circ} \mathrm{C}$ & 0 & $0 \%$ \\
\hline 5 & $27^{\circ} \mathrm{C}$ & $27,3^{\circ} \mathrm{C}$ & 0,3 & $1,11 \%$ \\
\hline \multicolumn{4}{|c|}{ Rata - rata kesalahan } & $1,28 \%$ \\
\hline
\end{tabular}

Tabel 4. Pengujian Sensor DHT22 (Kelembapan Udara)

\begin{tabular}{|c|c|c|c|c|}
\hline \multirow{2}{*}{ No } & \multicolumn{2}{|c|}{ Hasil Baca Kelembapan Udara } & \multirow{2}{*}{ Selisih } & \multirow{2}{*}{$\begin{array}{c}\text { Kesalahan } \\
(\%)\end{array}$} \\
\cline { 2 - 3 } & $\begin{array}{c}\text { Sensor } \\
\text { DHT22 }\end{array}$ & Hygrometer HTC-2 & & 5 \\
\hline 1 & $82 \%$ & $77 \%$ & 5 & $6,09 \%$ \\
\hline 2 & $83 \%$ & $80 \%$ & 3 & $3,61 \%$ \\
\hline 3 & $80 \%$ & $79 \%$ & 1 & $1,25 \%$ \\
\hline 4 & $80 \%$ & $80 \%$ & 0 & $0 \%$ \\
\hline 5 & $81 \%$ & $78 \%$ & 3 & 3,70 \\
\hline \multicolumn{3}{|c|}{ Rata - rata kesalahan } & $2,93 \%$ \\
\hline
\end{tabular}

Dari hasil pengujian sensor suhu dan kelembapan udara DHT22 diketahui memiliki pembacaan kadar suhu dan kelembapan udara pada jamur tiram putih dengan rata - rata error 1,28\% untuk suhu dan 2,93\% untuk kelembapan udara.

\subsection{Pengujian Sensor Kadar $\mathrm{pH}$ Tanah}

Pengujian Sensor Kadar $\mathrm{pH}$ Tanah dilakukan dengan cara membandingkan kadar $\mathrm{pH}$ tanah yang dideteksi oleh sensor dengan kadar $\mathrm{pH}$ tanah yang dideteksi oleh Soil Meter Analyzer. Hasil pengujian bisa dilihat pada tabel 5 .

Tabel 5. Pengujian Sensor Kadar pH Tanah

\begin{tabular}{|c|c|c|c|c|}
\hline \multirow{2}{*}{ No } & \multicolumn{2}{|c|}{ Hasil Baca Kadar $\mathrm{pH}$ Tanah } & \multirow{2}{*}{ Selisih } & \multirow{2}{*}{$\begin{array}{c}\text { Kesalahan } \\
(\%)\end{array}$} \\
\cline { 2 - 3 } & $\begin{array}{c}\text { Sensor } \mathrm{pH} \\
\text { Tanah }\end{array}$ & Soil Meter Analyzer & & \\
\hline 1 & 6,93 & 7,5 & 0,57 & $8,22 \%$ \\
\hline 2 & 7,26 & 7 & 0,26 & $3,71 \%$ \\
\hline 3 & 7,39 & 7,5 & 0,11 & $1,48 \%$ \\
\hline 4 & 7,32 & 7,5 & 0,18 & $2,45 \%$ \\
\hline 5 & 6,90 & 7 & 0,10 & $1,44 \%$ \\
\hline \multicolumn{4}{|c|}{ Rata - rata kesalahan } & $3,46 \%$ \\
\hline
\end{tabular}

Dari hasil pengujian sensor kadar $\mathrm{pH}$ tanah diketahui memiliki pembacaan kadar $\mathrm{pH}$ tanah pada baglog jamur tiram putih dengan rata - rata error 3,46 $\%$.

\subsection{Pengujian Sensor Ultrasonik}

Pengujian Sensor Ultrasonik dilakukan dengan cara membandingkan kapasitas air $(\mathrm{cm})$ yang dideteksi oleh sensor ultrasonik dengan kapasitas air $(\mathrm{cm})$ yang diukur oleh penggaris. Hasil dari pengujian dapat dilihat pada Tabel 6 . 
Tabel 6. Pengujian Sensor Ultrasonik

\begin{tabular}{|c|c|c|c|c|}
\hline \multirow{2}{*}{ No } & \multicolumn{2}{|c|}{ Hasil Baca Sensor Ultrasonik } & \multirow{2}{*}{ Selisih } & \multirow{2}{*}{$\begin{array}{c}\text { Kesalahan } \\
(\%)\end{array}$} \\
\cline { 2 - 3 } & $\begin{array}{c}\text { Sensor } \\
\text { Ultrasonik }\end{array}$ & Penggaris & & 0 \\
\hline 1 & $7 \mathrm{~cm}$ & $7 \mathrm{~cm}$ & $0,0 \%$ \\
\hline 2 & $8 \mathrm{~cm}$ & $6 \mathrm{~cm}$ & 2 & $0,25 \%$ \\
\hline 3 & $5 \mathrm{~cm}$ & $7 \mathrm{~cm}$ & 2 & $0,40 \%$ \\
\hline 4 & $10 \mathrm{~cm}$ & $6 \mathrm{~cm}$ & 4 & $0,66 \%$ \\
\hline 5 & $9 \mathrm{~cm}$ & $7 \mathrm{~cm}$ & 8 & $0,28 \%$ \\
\hline \multicolumn{4}{|c|}{ Rata - rata kesalahan } & $1,59 \%$ \\
\hline
\end{tabular}

Dari hasil pengujian sensor ultrasonik diketahui memiliki pembacaan kapasitas air $(\mathrm{cm})$ pada wadah air asam dan basa dengan rata - rata error $1,59 \%$.

\subsection{Pengujian Komunikasi dan Pengiriman Data ESP8266 (NodeMcu)}

Pengujian komunikasi dan pengiriman data pada ESP8266 (NodeMcu) ini menggunakan pengujian komunikasi dan pengiriman data dari sensor menuju database dan ditampilkan pada website monitoring. Untuk mengirim sebuah data, ESP8266 (NodeMcu) harus terlebih dahulu terkoneksi kepada jaringan LAN (Local Area Network) terlebih dahulu.

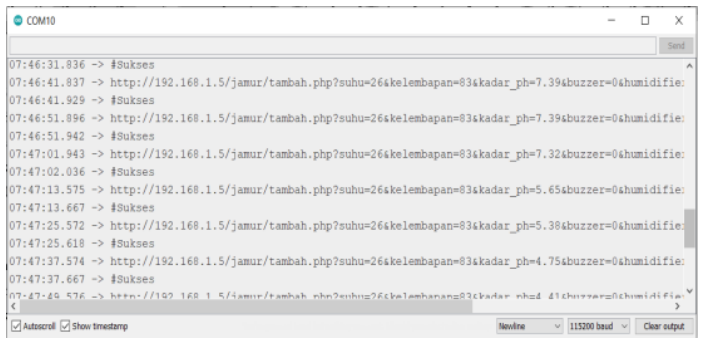

Gambar 7. Pengujian ESP8266

Berdasarkan Pengujian ESP8266 (NodeMcu) pada serial monitor menunjukan jika terhubung dan berhasil mengirimkan data maka akan menampilkan \#sukses, lalu jika tidak terhubung dan tidak berhasil mengirimkan data maka akan menampilkan \#. Selanjutnya data yang berhasil terkirim pada database akan langsung ditampilkan pada website monitoring. Data hasil penguijan dapat dilihat pada Tabel 7.

Tabel 7. Hasil Pengujian Pengiriman Data

\begin{tabular}{|c|c|c|c|}
\hline $\begin{array}{c}\text { Pengiriman } \\
\text { Ke }-\end{array}$ & $\begin{array}{c}\text { Terhubung } \\
\text { Ke AP }\end{array}$ & $\begin{array}{c}\text { Terhubung } \\
\text { ke Server }\end{array}$ & $\begin{array}{c}\text { Data Sukses } \\
\text { Dikirim }\end{array}$ \\
\hline 1 & Ya & Ya & Ya \\
\hline 2 & Ya & Ya & Ya \\
\hline 3 & Ya & Ya & Ya \\
\hline 4 & Ya & Ya & Ya \\
\hline 5 & Ya & Ya & Ya \\
\hline 6 & Ya & Ya & Ya \\
\hline 7 & Ya & Ya & Ya \\
\hline 8 & Ya & Ya & Ya \\
\hline 9 & Ya & Ya & Ya \\
\hline 10 & Ya & Ya & Ya \\
\hline
\end{tabular}

\subsection{Pengujian Waktu Delay Pengiriman Data ESP8266 (NodeMcu)}

Pengujian ini dilakukan dengan berbentuk pengiriman data dari sensor ke website. Hasil dari pengujian dapat dilihat Tabel 8.

Tabel 8. Pengujian Waktu Delay Pengiriman Data ESP8266 (NodeMcu)

\begin{tabular}{|c|c|c|c|c|}
\hline \multirow{2}{*}{ No } & \multicolumn{3}{|c|}{ Waktu } & \multirow{2}{*}{$\begin{array}{c}\text { Delay } \\
\text { (Detik) }\end{array}$} \\
\cline { 2 - 4 } & Tanggal & Pengiriman & $\begin{array}{c}\text { Tampil Pada } \\
\text { Website }\end{array}$ & 10 \\
\hline 1 & $01-02-2021$ & $01: 17: 19$ & $01: 17: 29$ & 10 \\
\hline 2 & $01-02-2021$ & $01: 17: 29$ & $01: 17: 39$ & 10 \\
\hline 3 & $01-02-2021$ & $01: 17: 39$ & $01: 17: 49$ & 10 \\
\hline 4 & $01-02-2021$ & $01: 17: 49$ & $01: 17: 5449$ & 10 \\
\hline 5 & $01-02-2021$ & $01: 18: 00$ & $01: 18: 10$ & 10 \\
\hline 6 & $01-02-2021$ & $01: 18: 10$ & $01: 18: 20$ & 10 \\
\hline 7 & $01-02-2021$ & $01: 18: 20$ & $01: 18: 30$ & 10 \\
\hline 8 & $01-02-2021$ & $01: 18: 30$ & $01: 18: 40$ & 10 \\
\hline 9 & $01-02-2021$ & $01: 18: 40$ & $01: 18: 50$ & 10 \\
\hline 10 & $01-02-2021$ & $01: 18: 51$ & $01: 19: 01$ & 10 \\
\hline
\end{tabular}

Dari Tabel 8 diatas, dapat diamati bahwa delay pada pengiriman data sudah sesuai yaitu sebesar 10 detik. Dengan delay sebesar 10 detik tersebut, digunakan untuk menjaga komponen agar tetap bekerja dengan optimal.

\subsection{Hasil implementasi Sistem Monitoring Pada Rumah Budidaya Jamur Tiram Putih}

Merupakan implementasi penempatan alat yang telah dijabarkan pada desain rangkaian alat terhadap miniatur rumah budidaya jamur tiram putih. Hasil Implementasi sistem monitoring pada rumah budidaya jamur tiram putih dapat dilihat pada gambar 8 dan gambar 9 .

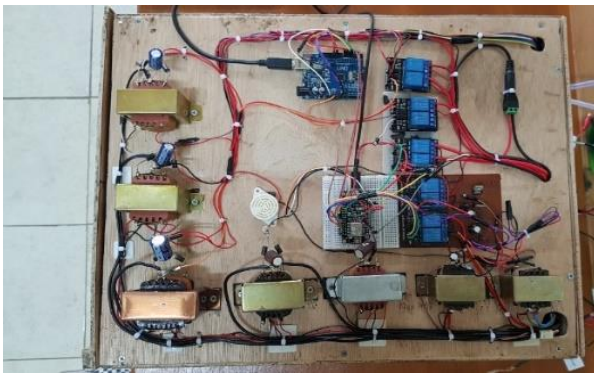

Gambar 8. Tampilan Atas Rumah Budidaya Jamur Tiram Putih

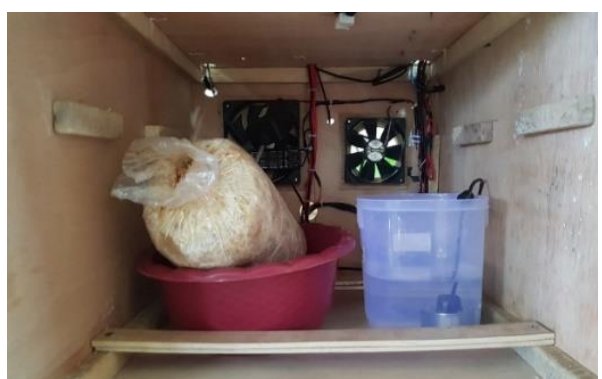

Gambar 9. Tampilan Dalam Rumah Budidaya Jamur Tiram Putih 


\subsection{Tampilan Halaman Home}

Tampilan Halaman home mempunyai fungsi untuk monitoring data secara real time dengan data terbaru dan adanya tampilan informasi kondisi dan aktuator. Tampilan halaman home pada Gambar 10.

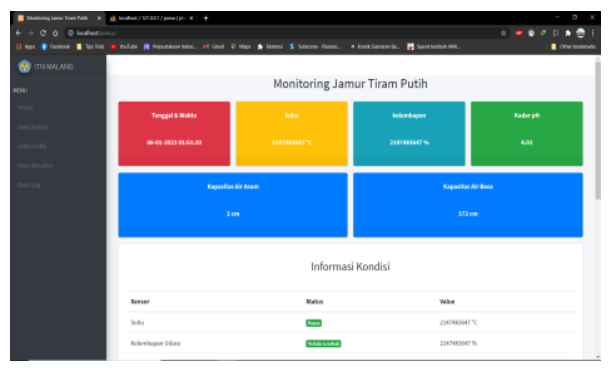

Gambar 10. Tampilan Halaman Home

\subsection{Tampilan Halaman Data Grafik}

Tampilan Halaman Data Grafik mempunyai fungsi untuk menampilkan grafik data suhu $\left({ }^{\circ} \mathrm{C}\right)$, kelembapan udara (\%), kadar $\mathrm{pH}$ tanah, kapasitas air asam $(\mathrm{cm})$, dan kapasitas air basa $(\mathrm{cm})$. Tampilan halaman data grafik pada Gambar 11.

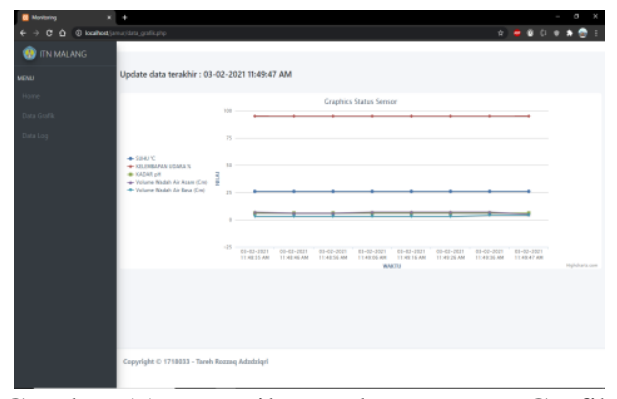

Gambar 11. Tampilan Halaman Data Grafik

\subsection{Tampilan Halaman Data Log}

Tampilan Halaman Data Log mempunyai fungsi untuk menampilkan riwayat data monitoring. Tampilan halaman data aktuator pada gambar 12 .

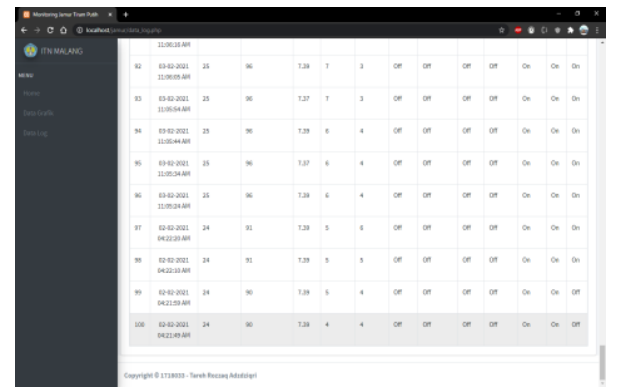

Gambar 12. Tampilan Halaman Data Aktuator

\subsection{Pengujian Fungsional Website}

Tabel 7. Pengujian fungsional Website

\begin{tabular}{|c|c|c|c|c|}
\hline \multirow[b]{2}{*}{ No } & \multirow[b]{2}{*}{ Aspek Pengujian } & \multicolumn{3}{|c|}{ Web Browser } \\
\hline & & $\begin{array}{l}\text { Chrome } \\
\text { (87.0.42) }\end{array}$ & $\begin{array}{c}\text { Microsoft } \\
\text { Edge } \\
(\text { (86.0.62) }\end{array}$ & $\begin{array}{l}\text { Mozilla } \\
\text { Firefox } \\
\text { (83.0) }\end{array}$ \\
\hline 1 & $\begin{array}{l}\text { Tampilan data tanggal \& } \\
\text { waktu, data sensor, informasi } \\
\text { kondisi, dan informasi } \\
\text { aktuator pada halaman utama }\end{array}$ & $\checkmark$ & $\checkmark$ & $\checkmark$ \\
\hline 2 & $\begin{array}{l}\text { Tampilan data grafik pada } \\
\text { halaman data grafik }\end{array}$ & $\checkmark$ & $\checkmark$ & $\checkmark$ \\
\hline 3 & $\begin{array}{l}\text { Tampilan data log pada } \\
\text { halaman data log }\end{array}$ & $\checkmark$ & $\checkmark$ & $\checkmark$ \\
\hline 4 & Responsive & $\checkmark$ & $\checkmark$ & $\checkmark$ \\
\hline
\end{tabular}

Keterangan :

$\checkmark$ : Berhasil

$\mathrm{x}$ : Tidak Berhasil.

Dapat dilihat dari tabel pengujian fungsional diatas bahwa aplikasi yang dibuat dapat berjalan dengan baik pada browser Google Chrome (87.0.42), Microsof Edge (86.0.2), dan Mozilla Firefox (83.0). Dengan hasil semua fungsi penampilan data pada halaman utama, data grafik, dan data log berhasil berfungsi dengan baik serta responsif karena aplikasi merupakan website responsif yang dibuat menggunakan pemrograman PHP.

\section{KESIMPULAN DAN SARAN}

\subsection{Kesimpulan}

Dari beberapa tahapan pengujian yang telah dilakukan, menghasilkan beberapa kesimpulan diantaranya :

1. Dari hasil pengujian sensor suhu dan kelembapan udara DHT22 diketahui memiliki pembacaan kadar suhu dan kelembapan udara pada baglog jamur tiram putih dengan rata - rata error 1,28 \% untuk suhu dan 2,93\% untuk kelembapan udara

2. Dari hasil pengujian sensor kadar $\mathrm{pH}$ tanah diketahui memiliki pembacaan kadar $\mathrm{pH}$ tanah pada baglog jamur tiram putih dengan rata - rata error $3,46 \%$.

3. Dari hasil pengujian sensor ultrasonik diketahui memiliki pembacaan tinggi permukaan air pada wadah air asam / basa dengan rata - rata error $1,59 \%$.

4. Dapat hasil pengujian ESP8266 (NodeMcu) diatas bahwa pengujian komunikasi dan pengiriman 10 data menggunakan ESP8266 (NodeMcu) berhasil terhubung kepada access point, server database, dan sukes melakukan pengiriman data ke database.

5. Dari hasil pengujian ESP8266 (NodeMcu) diketahui bahwa waktu pengiriman data dan waktu tampil pada website memiliki delay 10 detik. 
6. Website berjalan dengan baik pada web browser yang diujikan yaitu Google Chrome (87.0.4), Microsoft Edge (86.0.62), Mozilla Firefox (83.0).

\subsection{Saran}

Adapun saran yang diberikan untuk penelitian selanjutnya antara lain :

1. Pengembangan selanjutnya dapat menambahkan fitur notifikasi terkait kondisi pada rumah budidaya jamur tiram putih.

2. Menggunakan sensor yang tingkat sensitifitasnya lebih baik, agar pembacaan nilai sensor lebih akurat.

3. Dalam proses delay pengiriman data dapat diperkecil delay waktu menggunakan mikrokontroller atau modul wifi yang lebih baik, sehingga dapat lebih cepat dalam penyajian data (update).

\section{DAFTAR PUSTAKA}

[1] Agromedia, Pustaka. "Bertanam Jamur Konsumsi". Jakarta. PT. Agromedia Pustaka.(2002).

[2] Djumhawan R. Permana, Eisrin Risri Alda, and Pasaribu, Tahir. "Aneka Jamur Unggulan Yang Menembus Pasar”. Jakarta : Grasindo. (2002).

[3] Susilawati, dan Raharjo, B. "Petunjuk Teknis Budidaya Jamur Tiram (Pleurotus ostreatus var florida) yang Ramah Lingkungan (Materi Pelatihan Agribisnis bagi KMPH)". Palembang: Balai Pengkajian Teknologi Pertanian Sumatera Selatan. (2010).

[4] Nugraha Pangestu, Rizal Maulana, and Rakhmadhany Primananda. "Implementasi Sistem Monitoring Pada Rumah Jamur Menggunakan Jaringan Nirkabel Berbasis Protokol Komunikasi Message Queuing Telemetry Transport (MQTT)." Jurnal Pengembangan Teknologi Informasi dan Ilmu Komputer e-ISSN 2548: 964X. (2018).

[5] Dewi, Kartika, and Hafsah Nirwana. "Sistem Monitoring Dan Kontrol Suhu Serta Kelembaban Budidaya Jamur Tiram Berbasis Wireless Sensor Network." Seminar Nasional Hasil Penelitian \& Pengabdian Kepada Masyarakat (SNP2M). (2018).

[6] Soulthan, Deza Rijabi. "Perancangan Smart Monitoring System Pada Pembudidayaan Jamur Tiram Berbasis Pemrograman Arduino Dan Labview." (2018).

[7] Syas, Isnan Yusrian, and Frida Agung Rakhmadi. "Prototipe Sistem Monitoring Serta Kendali Suhu Dan Kelembapan Ruangan Budidaya Jamur Tiram Putih Menggunakan Sensor Dht22 Dan Mikrokontroler Nodemcu." Sunan Kalijaga Journal of Physics 1.1. (2019).
[8] Sinambela, Lazro Eko Putra Daniel. "Penerapan Iot (Internet Of Thing) Terhadap Sistem Pendeteksi Kesuburan Tanah Pada Lahan Perkebunan". Skripsi thesis, Institut Teknologi Nasional. (2020).

[9] Efendi, Yoyon. "Internet Of Things (Iot) Sistem Pengendalian Lampu Menggunakan Raspberry Pi Berbasis Mobile." Jurnal Ilmiah Ilmu Komputer, vol. 4, no. 2, 1 Sep. (2018).

[10] Vina Rahmawati, Aan Tohir Efendi 143310009."Sistem Pengendali Pintu Berbasis Web Menggunakan Nodemcu 8266”. Diploma thesis, STMIK AKAKOM Yogyakarta. (2017).

[11] Amrullah, Nafil Akhdan. "Alat Kontrol Suhu Dan Kelembaban Otomatis Pada Ruang Budidaya Jamur Tiram Berbasis Atmega32". Universitas 17 Agustus 1945 Surabaya. (2017).

[12] Wicaksono, Sigit Nugroho 133310002. "Aplikasi Kran Otomatis Berbasis Arduino”. Stmik Akakom Yogyakarta. (2017).

[13] Yuniawati, "Aplikasi Sensor Ultrasonik Hc-Sr04 Pada Alat Penyiram Tanaman Otomatis Bertenaga Solar Cell”. Other thesis, Politeknik Negeri Sriwijaya. (2017) .

[14] Depoinovasi, "depoinovasi.co.id", "Datasheet Sensor pH Tanah.”. [Online]. Available : https://depoinovasi.co.id/sensor-ph-tanahsupport-arduino/. Accesed 18 September 2020.

[15] Yulianto, Dwi - 185410171.'SSistem Pendeteksi Kebocoran Gas Menggunakan Sensor Mq-5 Berbasis Internet Of Things Dengan Nodemcu Esp8266 V.3". Skripsi thesis, Stmik Akakom Yogyakarta. (2020).

[16] Arifin, Jaenal, Intan Erlita Dewanti, and Danny Kurnianto. "Prototipe pendingin perangkat telekomunikasi sumber arus dc menggunakan smartphone." MEDIA ELEKTRIKA 10.1. (2017).

[17] Imelda Rahma, "Fimela.com", "Mengenal Humidifier Sebagai Alat Pengatur Kelembapan Udara, Lengkap Beserta Manfaat dan Cara Penggunaannya". [Online]. Avaiable : fimela.com/lifestylerelationship/read/4336074/mengenalhumidifier-sebagai-alat-pengatur-kelembapanudara-lengkap-beserta-manfaat-dan-carapenggunaannya. Accesed 19 September 2020.

[18] Nugraha, Yudha Satria Adhi. "Pengembangan Air Mancur Menari Mengikuti Irama Dan Bercahayakan Rgb Led (Dengan Sistem Monitoring Ketinggian Air)". Undergraduate (S1) thesis, University of Muhammadiyah Malang. (2018).

[19] Nabil, Nabil. "Stopkontak Pintar - Pengendalian Dan Monitoring Listrik Berbasis Android”. Undergraduate thesis, Universitas 17 Agustus 1945. (2017). 